Original Research Article

\title{
Knowledge, attitude and practice of pharmacovigilance towards adverse drug reactions reporting among health care professionals (nurses) in a tertiary care teaching hospital in Eastern India: an observational study
}

\author{
Debasish Misra*, Smita Das, Rasmirekha Behera, Karmajeet Rath, \\ Swati Mishra, Sudhansu Sekhar Mishra
}

Department of Pharmacology,

IMS \& SUM Hospital,

Bhubaneswar, Odisha, India

Received: 15 April 2019

Accepted: 13 May 2019

*Correspondence to:

Dr. Debasish Misra,

Email: debasishmisra@soa.ac.in

Copyright: (C) the author(s), publisher and licensee Medip Academy. This is an openaccess article distributed under the terms of the Creative Commons Attribution NonCommercial License, which permits unrestricted noncommercial use, distribution, and reproduction in any medium, provided the original work is properly cited.

\begin{abstract}
Background: Nursing staffs spend most time in patient care and are bedside caregivers. To expect voluntary reporting of adverse reactions, it is essential that they possess proper knowledge, right attitude and practice reporting. Therefore, the present study was aimed to assess the Knowledge, Attitude and Practice of Pharmacovigilance towards ADRs reporting.

Methods: A prospective, cross sectional, observational, questionnaire-based survey was conducted among nurses in a tertiary care teaching hospital in Eastern India. Questionnaire containing 15 questions was used to assess knowledge, attitude and practice. The questionnaire was administered to 150 nurses. Analysis of data was done using statistical software..

Results: The response rate in our study was $86.67 \%$. Nurses have good knowledge of pharmacovigilance and adverse reaction. However, only $10 \%$ have reported an adverse reaction in our study. This shows that in spite of having a good knowledge of reporting, nurses have poor attitude, which is reflected by a low reporting rate. Nurses opined that taking patient care is of prime importance than report an adverse reaction. This corroborates the low reporting rate in our set up.

Conclusions: Majority of nurses have good knowledge on pharmacovigilance and adverse drug reaction. The concern remains on the low reporting rate. Continuous training programmes, and reminders likely to enhance the voluntary reporting from the nursing staffs.
\end{abstract}

Keywords: Adverse reaction, KAP, Nurses, Pharmacovigilance

\section{INTRODUCTION}

The thalidomide disaster paved the way for World Health Organization (WHO) to initiate globalization of pharmacovigilance studies through establishment of global drug monitoring. WHO-approved national pharmacovigilance centres collect case reports and send to the Global database, at Uppsala, Sweden. ${ }^{1}$ WHO defines Pharmacovigilance as "The science and activities which are related to the detection, assessment, understanding and the prevention of adverse effects or any other drug related problems". ${ }^{2}$ This improves the safety profile, for use in diverse category of patient population. Pharmacovigilance Programme of India (PvPI), initially started functioning in 2010 from AIIMS, Delhi and later from Indian Pharmacopoeia Commission (IPC), Ghaziabad, in 2011, for better implementation and matching global standards in safety data. ${ }^{3}$ Studies revealed that ADRs are leading to 
hospitalization and constitute a significant economic burden on patients in India. ${ }^{4-6}$ WHO defines "adverse reactions as harmful and unintended responses to a drug and which occur with doses normally used in humans for prophylaxis, diagnosis or treatment of a disease or modifying a physiological function". ${ }^{7}$ Studies conducted in several parts of India have estimated the incidence of suspected adverse reactions to be nearly $2 \%$ to $3 \%$ among hospitalized patients. ${ }^{8,9}$ A recent systematic review estimated the median incidence of adverse reactions that led to hospitalization and those that developed during hospitalization as $2.85 \%$ and $6.34 \%$ respectively. ${ }^{10}$ Underreporting by health professionals is a major problem in India. $^{11}$

Nursing staffs spend most time in patient care and are bedside caregivers, and have a vital role in recognizing, and reporting of adverse event. For voluntary reporting of adverse reaction from nurses, it is essential that they should possess proper knowledge, right attitude. Therefore, the present study was done to evaluate the Knowledge, Attitude and Practice of Pharmacovigilance towards reporting amongst nursing staff in a Teaching Hospital in Eastern India.

\section{METHODS}

\section{Study design}

This study was a prospective, cross-sectional, observational, questionnaire - based study. The questionnaire was newly designed, based on the similar studies that have been conducted previously and was modified to make it relevant in our set up and was tested for its content validity. ${ }^{12-15}$ A questionnaire was prepared to assess knowledge, attitude toward pharmacovigilance, practice of reporting, identify the reasons of non-reporting and to evaluate the methods to improve the reporting rate. The study was conducted after receiving the approval from the Institutional Ethics Committee of IMS and SUM Hospital, Bhubaneswar.

\section{Study setting and time period}

The study was conducted in nursing staffs of IMS and SUM Hospital, Bhubaneswar. The study was conducted from $01 / 02 / 2019$ to $28 / 02 / 2019$, i.e., for one month.

\section{Study questionnaire}

The importance of the study and instructions on how to fill the questionnaire were explained to each respondent. Participants willing to be a part of the study, voluntarily agreed to sign the informed consent form. The questionnaire consists of demographic characteristics of the participants, knowledge of pharmacovigilance, attitude towards reporting, and practice of reporting, and also included questions on factors affecting non-reporting, and methods to improve the reporting rate. The participants were given 30 mins to provide the necessary information.
The response to each question was scored as 0 for incorrect and 1 for correct in knowledge question, 0 for disagree (non-favourable) and 1 for agree in attitude questions, and 0 for No and 1 for Yes in practice questions.

\section{Study participants}

Nurses working in different clinical departments of IMS \& SUM Hospital Bhubaneswar were included in the study. The questionnaire was administered to 150 nurses. Those who were not willing to participate, not submitting the form on time and incomplete responses were not included in present study.

\section{Statistical analysis}

The information was tabulated and analysed using the Microsoft Excel worksheet (Microsoft Office 2013). Frequency of response was calculated in percentage and presented as percentage $(\%)$ of respondents. Mean score and standard deviation were calculated for responses of knowledge, attitude and practices using SPSS version 20.0v (IBM Corp., Armonk, NY, USA).

\section{RESULTS}

Total 150 questionnaires were administered to nursing staffs, 130 forms were returned, and analysed as per the inclusion criteria. $86.67 \%$ was the response rate. A total of 10 Auxiliary Nurse Midwifery (ANM), 79 General Nursing Midwifery (GNM) and 41 B.Sc. Nursing staff were included in the study (Table 1).

Table 1: Demographic profile of study population categorized by qualification.

\begin{tabular}{|llll|}
\hline Parameters & ANM & GNM & $\begin{array}{l}\text { B.Sc. } \\
\text { Nursing }\end{array}$ \\
\hline $\begin{array}{l}\text { Mean Age } \\
\text { (Mean } \pm \text { SD) }\end{array}$ & $23.8 \pm 3.42$ & $24.0 \pm 2.82$ & $24.07 \pm 3.04$ \\
\hline Male: Female & $5: 5$ & $7: 72$ & $4: 37$ \\
\hline $\begin{array}{l}\text { Total Nursing } \\
\text { staff }\end{array}$ & 10 & 79 & 41 \\
\hline
\end{tabular}

Table 2: Mean score of respondents categorized by qualification.

\begin{tabular}{|llll|}
\hline Qualification & $\begin{array}{l}\text { Knowledge } \\
(\text { Mean } \pm \text { SD) }\end{array}$ & $\begin{array}{l}\text { Attitude } \\
(\text { Mean } \pm \text { SD) }\end{array}$ & $\begin{array}{l}\text { Practice } \\
(\text { Mean } \pm \text { SD) }\end{array}$ \\
\hline \multirow{2}{*}{ ANM } & 0.675 & 0.625 & 0.675 \\
& \pm 0.168 & \pm 0.270 & \pm 0.168 \\
\hline \multirow{2}{*}{ GNM } & 0.637 & 0.696 & 0.637 \\
& \pm 0.238 & \pm 0.157 & \pm 0.238 \\
\hline B.Sc. & 0.693 & 0.631 & 0.693 \\
Nursing & \pm 0.215 & \pm 0.233 & \pm 0.215 \\
\hline
\end{tabular}

The mean score of knowledge and practice was lowest in the GNM group and highest in the B.Sc. Nursing group. The mean score of attitudes was lowest in the ANM group 
and highest in the GNM group. Maximum adverse reactions were reported by the B.Sc. Nursing staff in present study (Table 2).

GNM nurses were more aware of the Indian agency involved in drug safety issues, adverse reaction collaborating centres, type of reactions to be reported, healthcare professionals are responsible for reporting, and there is no legal consequence for reporting. B. Sc qualified nurses were more aware of adverse reaction definition, meaning of PvPI. However, only 5\% of GNM nurses have ever reported, which is the lowest amongst study groups (Table 3).

Table 3: Knowledge, attitude, practice of reporting ADR based on qualification.

\begin{tabular}{|lllll|}
\hline $\begin{array}{l}\text { Knowledge, attitude and practice } \\
\text { related questions }\end{array}$ & $\begin{array}{l}(\mathbf{A N M}) \\
\text { Correct Response } \\
\mathbf{N}(\%)\end{array}$ & $\begin{array}{l}\text { (GNM) } \\
\text { Correct Response } \\
\mathbf{N}(\%)\end{array}$ & $\begin{array}{l}\text { (B.Sc. Nursing) } \\
\text { Correct Response }\end{array}$ & $\begin{array}{l}\text { N }(\%) \\
\text { p value }\end{array}$ \\
\hline Pharmacovigilance definition & $9(90)$ & $57(72.15)$ & $34(82.92)$ & 0.143 \\
\hline International ADR centre & $5(50)$ & $46(58.22)$ & $20(48.78)$ & 0.705 \\
\hline Indian agency involved in ADR & $6(60)$ & $49(62.02)$ & $17(41.46)$ & 0.143 \\
\hline ADR definition & $9(90)$ & $67(84.81)$ & $37(90.24)$ & 0.389 \\
\hline Meaning of PvPI & $8(80)$ & $65(82.27)$ & $39(95.12)$ & $0.044 *$ \\
\hline National ADR centre & $7(70)$ & $55(69.62)$ & $26(63.41)$ & 0.906 \\
\hline Which ADR to be reported & $8(80)$ & $67(84.81)$ & $31(75.61)$ & 0.702 \\
\hline HCPs responsible for ADR reporting & $9(90)$ & $74(93.67)$ & $36(87.80)$ & 0.883 \\
\hline ADR centre in each hospital & $8(80)$ & $75(94.94)$ & $33(80.49)$ & 0.107 \\
\hline Is reporting of ADR necessary & $7(70)$ & $69(87.34)$ & $27(65.85)$ & $0.044 *$ \\
\hline $\begin{array}{l}\text { Is there legal consequence of ADR } \\
\text { reporting }\end{array}$ & $9(90)$ & $75(94.94)$ & $35(85.36)$ & 0.502 \\
\hline Trained on how to report ADR & $10(100)$ & $70(88.61)$ & $37(90.24)$ & 0.378 \\
\hline Seen ADR reporting form & $10(100)$ & $70(88.61)$ & $37(90.24)$ & 0.378 \\
\hline Confidentiality to be maintained & $6(60)$ & $60(75.95)$ & $29(70.73)$ & 0.599 \\
\hline Ever reported an ADR & $1(10)$ & $4(5.06)$ & $8(19.51)$ & $0.036^{*}$ \\
\hline
\end{tabular}

*Significant (calculated by Chi-square test), ADR - Adverse Drug Reaction, HCPs - Health care professionals, PvPI - Pharmacovigilance program of India, KAP - Knowledge, Attitude, Practice

Table 4: Assessment of knowledge about ADR reporting.

\begin{tabular}{|lll|}
\hline Knowledge related questions & Correct response N $(\%)$ & Incorrect response $\mathbf{N}(\%)$ \\
\hline Definition of pharmacovigilance & $100(76.9)$ & $30(23.1)$ \\
\hline Location of International ADR collaborating centre & $71(54.6)$ & $59(45.4)$ \\
\hline Agency in India involved in ADR (drug safety) issues & $72(55.4)$ & $58(44.6)$ \\
\hline Definition of ADR & $113(86.9)$ & $17(13.1)$ \\
\hline Meaning of PvPI & $112(86.2)$ & $18(13.8)$ \\
\hline ADR and PV national coordination centre location & $88(67.7)$ & $42(32.3)$ \\
\hline Which ADR should be reported & $106(81.5)$ & $24(18.5)$ \\
\hline
\end{tabular}

Total $76.9 \%$ of the respondents knew the definition of pharmacovigilance, $54.6 \%$ knew the location of International ADR collaborating centre, $55.4 \%$ knew the name of the agency involved in drug safety issues in India.

The meaning of adverse reaction and PvPI was correct in $86.9 \%$ and $86.2 \%$ of the study population, respectively. $67.7 \%$ and $81.5 \%$ could correctly identify the location of national coordination centre, the type of reactions which should be reported, respectively (Table 4).
Total $91.5 \%$ responded that healthcare professionals should report an adverse reaction, $89.2 \%$ were of the opinion that adverse reaction reporting centre should be established in each hospital, $79.2 \%$ agreed that reporting is necessary and $91.5 \%$ disagreed that there is a legal consequence of reporting (Table 5).

Total $90 \%$ of the respondents had undergone training on reporting. $73.1 \%$ were of the opinion that confidentiality is to be maintained while reporting and only $10 \%$ have ever reported in present study (Table 6). 
Total $49.2 \%$ responded that taking care of patients is more vital than reporting. $22.3 \%$ did not know how to report and $5.4 \%$ did not know where to report. $10 \%$ think that reporting is not important.

Total $6.9 \%$ and $6.2 \%$ feel that no remuneration and legal liability are the factors in nonreporting (Table 7).

Table 5: Assessment of attitude about ADR reporting.

\begin{tabular}{|lll|}
\hline Attitude related Questions & $\begin{array}{l}\text { Agreed } \\
\mathbf{N}(\%)\end{array}$ & $\begin{array}{l}\text { Disagreed } \\
\mathbf{N}(\%)\end{array}$ \\
\hline $\begin{array}{l}\text { Healthcare professionals } \\
\text { responsible for ADR } \\
\text { reporting }\end{array}$ & $\begin{array}{l}119 \\
(91.5)\end{array}$ & $11(8.5)$ \\
\hline $\begin{array}{l}\text { Establishing ADR centre in } \\
\text { each hospital }\end{array}$ & $\begin{array}{l}116 \\
(89.2)\end{array}$ & $14(10.8)$ \\
\hline $\begin{array}{l}\text { Is reporting of ADR } \\
\text { necessary }\end{array}$ & $\begin{array}{l}103 \\
(79.2)\end{array}$ & $27(20.8)$ \\
\hline $\begin{array}{l}\text { Is there legal consequence } \\
\text { for ADR reporting? }\end{array}$ & $11(8.5)$ & $119(91.5)$ \\
\hline
\end{tabular}

Table 6: Assessment of practice about ADR reporting.

\begin{tabular}{|lll|}
\hline Practice related Questions & Yes & No \\
& N (\%) & N (\%) \\
\hline Trained on how to report ADR & $117(90)$ & $13(10)$ \\
\hline Seen an ADR reporting form & $117(90)$ & $13(10)$ \\
\hline $\begin{array}{l}\text { Confidentiality to be maintained } \\
\text { while reporting an ADR }\end{array}$ & $95(73.1)$ & 35 \\
\hline Ever reported an ADR & $13(10)$ & $117(90)$ \\
\hline
\end{tabular}

Table 7: Factors affecting nonreporting of an ADR.

\begin{tabular}{|ll|}
\hline Factors & $\begin{array}{l}\text { Respondents } \\
\text { N }(\%)\end{array}$ \\
\hline Did not know how to report & $29(22.3)$ \\
\hline Did not know where to report & $07(5.4)$ \\
\hline Did not think is important to report & $13(10)$ \\
\hline $\begin{array}{l}\text { Taking care of patients is more vital } \\
\text { than reporting }\end{array}$ & $64(49.2)$ \\
\hline No remuneration & $09(6.9)$ \\
\hline Legal liability & $08(6.2)$ \\
\hline
\end{tabular}

Table 8: Different methods to increase reporting of ADRs.

\begin{tabular}{|ll|}
\hline $\begin{array}{l}\text { Methods to increase reporting } \\
\text { ADR }\end{array}$ & $\begin{array}{l}\text { Respondents } \\
\text { N }(\%)\end{array}$ \\
\hline $\begin{array}{l}\text { Conducting } \\
\text { training/workshops/CME }\end{array}$ & $60(46.2)$ \\
\hline $\begin{array}{l}\text { Providing acknowledgement receipt } \\
\text { to the reporter }\end{array}$ & $24(18.5)$ \\
\hline Appreciation of the reporter & $28(21.5)$ \\
\hline $\begin{array}{l}\text { Reminders and increased awareness } \\
\text { from the ADR monitoring } \\
\text { committee }\end{array}$ & $18(13.8)$ \\
\hline
\end{tabular}

Total $46.2 \%$ suggested conducting training, workshops, $21.5 \%$ need appreciation for reporting, $18.5 \%$ seek acknowledgement receipt and $13.8 \%$ need increased awareness from the ADR monitoring committee in the form of reminders for improving the rate of spontaneous reporting (Table 8).

\section{DISCUSSION}

Nurses spend maximum time with the patients in delivering quality healthcare, and probably the first to alert the physician on adverse reactions. There are very few studies done only on nursing population in India. Thus, an important reason to include nurses in present study and encourage them for contribution to the reporting system. ${ }^{16,17}$ The response rate in present study was $86.67 \%$ against $63 \%, 65 \%$ and $67.33 \%$ in study done at Mangalore, Delhi and Perambalur, respectively. ${ }^{18-20}$

\section{Assessment of knowledge}

Total $76.9 \%$ knew the meaning of pharmacovigilance, as compared to $68.27 \%, 62.4 \%, 38.6 \%$ and $44.34 \%$ by Amrita $\mathrm{P}$ et al, Gupta SK et al, Patil AP et al, Kumari S et al, respectively. ${ }^{19-22}$ International ADR collaborating centre was known to $54.6 \%$, as compared to $41.6 \%, 1.48 \%$ and $17.39 \%$ by Gupta SK et al, Patil AP et al, and Kumari S et al, respectively. ${ }^{20-22} 55.6 \%$ knew the agency in India, which is involved in drug safety issues, as compared to $78.2 \%$ and $28.26 \%$ by Gupta SK et al, and Kumari $\mathrm{S}$ et al, respectively. ${ }^{20,22}$

The meaning of adverse reaction was known to $86.9 \%$, as compared to $51.92 \%$ by Amrita $\mathrm{P}$ et al. ${ }^{19}$ The meaning of PvPI was known to $86.2 \%$, against $75.2 \%$ and $79.77 \%$ by Gupta SK et al, and Patil AP et al, respectively. ${ }^{20,21}$ National adverse reaction collaborating centre was known to $67.7 \%$ against only $0.99 \%$ by Patil AP et al. ${ }^{21}$ The type of adverse reaction to be reported is known to $81.5 \%$, as compared to only $15.2 \%$ by Hanafi $\mathrm{S}$ et al..$^{23}$

\section{Assessment of attitude}

Total $91.5 \%$ responded that health care professionals are responsible for reporting, as compared to $93.25 \%, 91 \%$, and $80.2 \%$ by Scandashree $\mathrm{K}$ et al, Hajebi $\mathrm{G}$ et al, and Gupta SK et al, respectively. ${ }^{18,20,24} 89.2 \%$ believed that establishing a reporting centre is necessary in each hospital, as compared to $74.3 \%$ and $70.86 \%$ by Gupta SK et al, and Kumari $\mathrm{S}$ et al, respectively. ${ }^{20,22}$ Total $79.2 \%$ responded that reporting is necessary, which was quite low as compared to $97.1 \%, 97 \%, 90.59 \%, 90 \%, 94 \%$ by Amrita P et al, Gupta SK et al, Patil AP et al, Kumari S et al, and Ganesan $S$ et al, respectively. ${ }^{19-22,25}$

\section{Assessment of practice}

Total $90 \%$ were previously trained on reporting, as compared to $53.5 \%, 70 \%$ and $5 \%$ by Gupta SK et al, Kumari $\mathrm{S}$ et al, and Ganesan $\mathrm{S}$ et al, respectively. ${ }^{20,22,25}$ 
$90 \%$ have seen a reporting form as compared to $58.4 \%$ by Gupta SK et al. ${ }^{20}$ Total $73.1 \%$ stated that confidentiality is to be maintained while reporting as compared to $62.37 \%$ by Patil AP et al. ${ }^{21}$

Only $10 \%$ have reported, as compared to $11.1 \%, 90.38 \%$, $22.8 \%, 92 \%, 25 \%$ and $45 \%$ by Scandashree K et al, Amrita P, Gupta SK et al, Hajebi G et al, Ganesan S et al, and Adiga SMN respectively. ${ }^{18-24,25,26}$ In Amrita $P$ et al, and Hajebi $\mathrm{G}$ et al, study, nurses have reported $79.81 \%$ and $56 \%$ of ADR to the physicians respectively. ${ }^{19,24}$

\section{Factors affecting nonreporting of an ADR}

Total $22.3 \%$ did not know how to report, $5.4 \%$ did not know where to report and $10 \%$ does not find any necessity to report, as compared with $27.27 \%, 25.45 \%, 5.45 \%$ by Adiga SMN, respectively. ${ }^{26}$

About $49.2 \%$ replied that taking care of patients is more vital than making report which was quite high compared to $23.8 \%$ by Gupta SK et al. ${ }^{20}$ This corroborates the low reporting rate of adverse reaction in our hospital. 38.26\% by Kumari S et al, and $63.63 \%$ by Adiga SMN replied lack of time for nonreporting. ${ }^{22,26} 6.9 \%$ replied no remuneration for nonreporting as compared with $51.98 \%, 31.7 \%$, and $23.47 \%$ by Scandashree $\mathrm{K}$ et al, Gupta SK et al, and Kumari $\mathrm{S}$ et al, respectively. ${ }^{18,20,22} 6.2 \%$ stated legal liability for nonreporting as compared to $14.5 \%$ by Adiga SMN. ${ }^{26}$

\section{Methods to increase response for voluntary reporting}

Total $46.2 \%$ in present study require more training and workshop, as compared to $92.31 \%$ by Amrita $\mathrm{P}$ et al. ${ }^{19}$ Acknowledgement to the reporter and appreciation of the reporter was reported by $18.5 \%$ and $21.5 \%$ of the study population. $13.5 \%$ suggested for reminders and awareness as compared to $82.5 \%$ by Adiga SMN. ${ }^{26}$ Majority of nurses require training programmes, reminders to improve the spontaneous reporting rate.

\section{CONCLUSION}

Majority of nurses have good knowledge on pharmacovigilance and adverse reaction. The concern remains on the low reporting rate. This can be due to their poor attitude towards reporting. Continuous training programmes, and reminders likely to enhance the voluntary reporting from our nursing staffs.

\section{ACKNOWLEDGEMENTS}

Authors would like to thank the nursing staffs who participated in present study.

Funding: No funding sources Conflict of interest: None declared

Ethical approval: The study was approved by the Institutional Ethics Committee ((DMR/IMS.SH/180104)

\section{REFERENCES}

1. Güner MD, Ekmekci PE. Healthcare professionals' pharmacovigilance knowledge and adverse drug reaction reporting behavior and factors determining the reporting rates. J Drug Assess. 2019;8(1):13-20.

2. Pharmacovigilance. World Health Organization 2016 Available at: http://www.who.int/medicines/areas/quality_safety/sa fety_efficacy/pharmvigi/en/.

3. Kalaiselvan V, Srivastava S, Singh A, Gupta SK. Pharmacovigilance in India: Present Scenario and Future Challenges. Drug Saf. 2019:1-8.

4. Patel KJ, Kedia MS, Bajpai D, Mehta SS, Kshirsagar NA, Gogtay NJ. Evaluation of the prevalence and economic burden of adverse drug reactions presenting to the medical emergency department of a tertiary referral centre: a prospective study. BMC Clin Pharmacol. 2007 Dec;7(1):8.

5. Raut A, Diwan A, Patel C, Patel P, Pawar A. Incidence, severity and financial burden associated with adverse drug reactions in medicine inpatients. Asian J Pharm Clin Res. 2011;4(2):103-11.

6. Khan FA, Nizamuddin S, Huda N, Mishra H. A prospective study on prevalence of adverse drug reactions due to antibiotics usage in otolaryngology department of a tertiary care hospital in North India. Int J Basic Clin Pharmacol. 2013;2(5):548-53.

7. Avery AJ, Anderson C, Bond CM, Fortnum H, Gifford A, Hannaford PC, et al. Evaluation of patient reporting of adverse drug reactions to the UK 'yellow card scheme': Literature review, descriptive and qualitative analyses, and questionnaire surveys. Health Technol Assess. 2011;15(20):1-234.

8. Sriram S, Ghasemi A, Ramasamy R, Devi M, Balasubramanian R, Ravi TK, et al. Prevalence of adverse drug reactions at a private tertiary care hospital in south India. J Res Med Sci Off J Isfahan Univ Med Sci. 2011;16(1):16-25.

9. Doshi MS, Patel PP, Shah SP, Dikshit RK. Intensive monitoring of adverse drug reactions in hospitalized patients of two medical units at a tertiary care teaching hospital. J Pharmacol Pharmacother. 2012;3(4):30813.

10. Patel TK, Patel PB. Incidence of Adverse Drug Reactions in Indian Hospitals: A Systematic Review of Prospective Studies. Curr Drug Saf. 2016;11(2):128-36.

11. Tandon VR, Mahajan V, Khajuria V, Gullani Z. Under-reporting of adverse drug reactions: A challenge for pharmacovigilance in India. Indian $\mathbf{J}$ Pharmacol. 2015; 47 (1):65-71.

12. Desai CK, Iyer PG, Panchal J, Shah S, Dikshit RK. An evaluation of knowledge, attitude, and practice of adverse drug reaction among prescriber at a tertiary care hospital. Perspect Clin Res. 2011;2(4):129-36.

13. Rajesh R, Vidyasagar S, Varma DM. An educational intervention to assess knowledge, attitude, practice of pharmacovigilance among healthcare professional in 
an Indian tertiary care teaching hospital. Int J Pharm Tech Res. 2011;3(2):678-92.

14. Khan SA, Goyal C, Chandel N, Rafi M. Knowledge, attitudes, and practice of doctors to adverse drug reaction reporting in a teaching hospital in India: An observational study. J Nat Sci Biol Med. 2013;4(1):191-6.

15. Gupta P, Udupa A. Adverse drug reaction reporting and pharmacovigilance: Knowledge, attitudes and perceptions amongst resident doctors. J Pharm Sci Res. 2011;3:1064-9.

16. Hall M, McCormack P, Arthurs N, Feely J. The spontaneous reporting of adverse drug reactions by nurses. Br J Clin Pharmacol. 1995;40(2):173-5.

17. Backstrom M, Ekman E, Mjorndal T. Adverse drug reaction reporting by nurses in Sweden. Eur $\mathrm{J}$ Clin Pharmacol. 2007;63(6):613-8.

18. Scandashree K, Praveen Kumar B, Padmaja Udaykumar, Tanya Mary Thomas. Knowledge, attitude, and practice of adverse drug reaction reporting among nurses in a South Indian tertiary health-care centre. Natl J Physiol Pharm Pharmacol. 2017;7(2):143-146.

19. Amrita P, Kharbanda B. Knowledge, attitude and skills of nurses of Delhi towards adverse drug reaction reporting. Indian J Pharm Pract. 2012; 5(1):45-51.

20. Gupta SK Nayak RP, Shivaranjani R, Vidyarthi SK. A questionnaire study on the knowledge, attitude, and the practice of pharmacovigilance among the healthcare professionals in a teaching hospital in South India. Perspect Clin Res. 2015;6(1):45-52.

21. Patil AP, Shirure PA, Khobragade RS. Awareness study of Pharmacovigilance among the health care professionals (nursing staff) at tertiary care hospital,
Solapur, Maharashtra, India. Int J Res Med Sci. 2017;5(8):3596-99.

22. Kumari S, Saxena A, Senthilkumar P. Evaluation of Knowledge, Awareness, and Attitude Practice among nurses in Pharmacovigilance at Tertiary care hospital in Delhi. J Harmo Res Pharm. 2015, 4(1):76-86.

23. Hanafi S, Torkamandi H, Hayatshahi A, Gholami K, Javadi M. Knowledge, attitudes and practice of nurse regarding adverse drug reaction reporting. Iranian $\mathbf{J}$ Nursing Midwifery Res. 2012;17(1):21.

24. Hajebi G, Mortazavi SA, Salamzadeh J, Zian A. A survey of knowledge, attitude and practice of nurses towards pharmacovigilance in Taleqani Hospital. Iran J Pharm Res. 2010;9(2):199-206.

25. Ganesan S, Gunaseelan V, Reddy KC, Subrahmanyam DK, Adithan C. A Survey on Knowledge, Attitude and Practice of Pharmacovigilance towards Adverse drug reactions reporting among Doctors and Nurses in a Tertiary Care Hospital in South India. J Young Pharm. 2016;8(4):471-6.

26. Adiga SMN, Banavalikar NP. Knowledge, attitude and practice of adverse drug reaction monitoring and reporting among nurses of secondary healthcare. Int J Basic Clin Pharmacol. 2016; 5(4):1574-9.

Cite this article as: Misra D, Das S, Behera R, Rath K, Mishra S, Mishra SS. Knowledge, attitude and practice of pharmacovigilance towards adverse drug reactions reporting among health care professionals (nurses) in a tertiary care teaching hospital in Eastern India: an observational study. Int J Basic Clin Pharmacol 2019;8:1403-8. 